\title{
Hanford Position Paper on Accuracy and Calibration of 3013 Balance and 9975 Drum Scale
}

Prepared for the U.S. Department of Energy

Assistant Secretary for Environmental Management

Project Hanford Management Contractor for the

U.S. Department of Energy under Contract DE-AC06-96RL13200

\section{FLUOR}

P.O. Box 1000

Richland, Washington 
HNF-34155

HNF- Revision 0

EDC \#: HNEDC-07-34156

de for BDP

6128107

\section{Hanford Position Paper on Accuracy and Calibration of 3013 Balance and 9975 Drum Scale}

Document Type: TI

Program/Project: PFP

B. D. Pritchett

Fluor Hanford, Inc.

Date Published

June 2007

Prepared for the U.S. Department of Energy

Assistant Secretary for Environmental Management

Project Hanford Management Contractor for the

U.S. Department of Energy under Contract DE-AC06-96RL13200

\section{FLUOR}

P.O. Box 1000

Richland, Washington
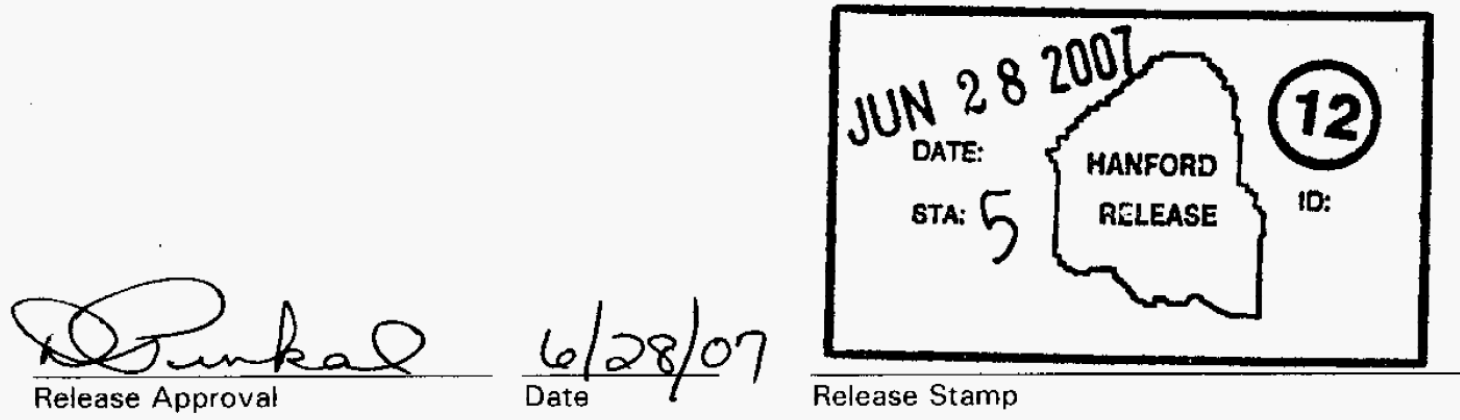

DOES NOT CONTAIN CLASSIFIED OR

UNCLASSIFIEO CONTROLLEO

NUCLEAR INFORMATION

\section{Approved for Public Release;}

Further Dissemination Unlimited

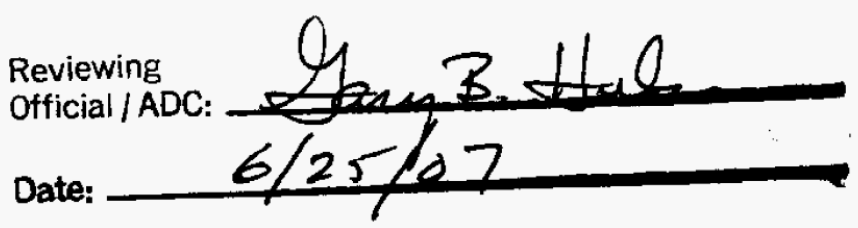


TRADEMARK DISCLAIMER

Reference herein to any specific commercial product, process,

or service by trade name, trademark, manufacturer, or

otherwise, does not necessarily constitute or imply its

endorsement, recommendation, or favoring by the United

States Government or any agency thereof or its contractors or

subcontractors.

This report has been reproduced from the best available copy.

Printed in the United States of America

Total Pages: 32 
Hanford Position Paper

Subject: $\quad$ Accuracy and Calibration of 3013 Balance and 9975 Drum Scale

Requirement Document: NMS-13659, Revision 1, Shipper/Receiver Agreement between the Savannah River Site and the Hanford Site, Section 6.1(c) \& (e).

PFP Implementing Documents: $\quad$ Maintenance Procedure 1-ZM-076, Balances 2736$\mathrm{ZB}$ and 2736-Z Vault (see data sheet 7)

Operations Procedure ZO-300-204, Load 9975

Shipping Container

Maintenance Procedure 1-ZM-149, Calibration of Mettler Toledo ${ }^{(\mathbb{1})}$ Drum Scale

\section{Introduction}

Shipping of materials between different locations requires methods for confirming that the correct quantities and materials are shipped and received intact. The quickest method for confirming the correct quantity of material is to weigh the material on a balance. In order for the shipper's and receiver's balances to agree, the balances must use a traceable method of periodic calibration. Once calibrated, the balances must be rechecked periodically with accepted standards to confirm that the balances remain within the allowable tolerances.

This letter affirms that the balances used for weighing 3013 containers and 9975 shipping packages are staying within allowable accepted tolerances and that there is no discernable "drift" in the weighings that might indicate future trouble with the balance.

\section{Weighing of 3013 Container Prior to Placement within 9975 PCV:}

Each 3013 is weighed on a Mettler Toledo ${ }^{(1)}$ Model SG16001 balance prior to loading into the primary containment vessel of the 9975 shipping container. The accuracy of this balance is confirmed with weight standards every day that it will be used during loading campaigns in accordance with Calibration Procedure 1-ZM-076. The balance is adjusted per 1-ZM-076, Section 4.2, "Calibration Sequence," if the balance response is outside the tolerance for any of the designated weight standards. The weight standards meet the requirements for National Institute of Standards and Technology (NIST) "S" standards. The tolerances for the weights used are:

500 grams $\quad$ plus or minus 0.1 grams

1 kilogram plus or minus 0.2 grams

5 kilograms plus or minus 1.0 grams

10 kilograms plus or minus 2.0 grams

15 kilograms plus or minus 3.0 grams

\footnotetext{
${ }^{1}$ Mettler Toledo is a registered trademark of Mettler-Toledo, Inc.
} 
The operational 3013 gross weight measurements are recorded on both Data Sheet 1 and Data Sheet 2 of the ZO-300-204 loading procedure. The current range for Hanford 3013 gross weights is between $7.492 \mathrm{~kg}$ minimum to $12.397 \mathrm{~kg}$ maximum.

A trending review was performed on the calibration data sheets from January 2003 through the present to evaluate tolerance variances over time. The data for the three key weights at 5,000 g, 10,000 g, and 15,000 g were entered into a Microsoft Excel ${ }^{(\mathrm{s}) 2}$ spreadsheet. These data were compared to the allowable tolerances to express the difference in indicated weight on the balance with the known weight of the standard weights. The differences were calculated as fractions of the allowable tolerances. The data are listed in Spreadsheet 1. The results are shown graphically in Figure 1.

The data for the three studied weights show that the balance indicated weights outside acceptable tolerances for at least one weight on 6 occasions in the $4+$ years of the weight records in the spreadsheet. On each occasion, the calibration section of the procedure was used to put the balance back in calibration. Rechecks of the weights showed that the balance indications went back into the acceptable tolerances every time. The worst departure from the acceptable tolerances was an indication of $4995.4 \mathrm{~g}$ for a check weight of $5000.0 \mathrm{~g}$. This difference was 4.6 times the allowable deviation of $+/-1 \mathrm{~g}$ for that weight, but the deviation is still less than $0.1 \%$ of the correct value. Visual examination of Figure 1 shows that the deviations from the exact weights occur upward and downward in an apparently random fashion; thus, there is no discernable "drift" in the balance indications.

\section{Weighing of Loaded 9975 Container:}

The gross weight for each loaded Hanford 9975 is performed per PFP Procedure ZO-300204, Load 9975 Shipping Package and the results recorded on both Data Sheet 1 and Data Sheet 4 to that procedure. The measurements are performed in Room 638 of the 2736-ZB building using a Mettler Toledo ${ }^{\circledR 1}$ Model LYNX ${ }^{(133}$ Drum Scale. Calibration of this scale is performed per Calibration Procedure 1-ZM-149, Calibration of Mettler Toledo ${ }^{18}$ Drum Scale System 74D, using National Institute of Standards and Technology (NIST) check weights with an accuracy of National Standard "S" tolerance. This balance is checked daily prior to use. An extensive effort by Fluor Hanford, including

discussions with Mettler Toledo ${ }^{\mathbb{1}}$, resulted in narrowing the tolerances from $+/-0.6 \mathrm{lb}$ to $+/-0.2 \mathrm{lb}$ in 2005 . The changes in weights checked and the tolerances used are described in Table 1, below.

\section{TABLE 1}

\section{METTLER TOLEDO ${ }^{10}$ BALANCE CHECK WEIGHTS AND TOLERANCES}

\begin{tabular}{|l|l|l|}
\hline Time Period & Weights Checked & Allowed Tolerances \\
\hline $\begin{array}{l}\text { September 2003 through } \\
\text { March 2005 }\end{array}$ & $0,200,400$, and 600 pounds & $\begin{array}{l}+/-0.6 \text { pound at all weights } \\
\text { listed }\end{array}$ \\
\hline $\begin{array}{l}\text { July 2005 through the } \\
\text { present }\end{array}$ & $\begin{array}{l}0,100,200,300,400, \text { and } \\
500 \text { pounds }\end{array}$ & $\begin{array}{l}+/-0.2 \text { pound at all weights } \\
\text { listed }\end{array}$ \\
\hline
\end{tabular}

${ }^{2}$ Microsoft and Excel are registered trademarks of Microsoft Corporation.

${ }^{3}$ LYNX is a registered trademark of Mettler-Toledo, Inc. 
Data sheets from September 2003 through the present were reviewed for the same comparisons made on the 3013 balance, as described above. Spreadsheet 2 lists these data for the $200 \mathrm{-g}, 400 \mathrm{-g}$, and $500 \mathrm{-g} / 600 \mathrm{-g}$ weight standards. Figure 2 depicts the data graphically.

The data show that the Mettler Toledo balance was outside the allowable tolerance range only one time and, then, for only one weight standard $(600 \mathrm{~g})$. The indicated weight was $599.29 \mathrm{~g}$ when the minimum allowable weight indication was $599.40 \mathrm{~g}$. The balance has been within tolerances every time since then, even though the tolerance range was reduced from $+/-0.6 \mathrm{lb}$. to $+/-0.2 \mathrm{lb}$. in 2005 .

This balance consistently indicated weights that were lower than the actual weights until the balance was recalibrated and checked with tighter tolerances starting in 2005 . The few data available since then indicate that the balance indicates slightly higher than the real weights, but more data will be needed for a meaningful study at the new tolerances.

\section{Independent Verification with NIST Standards}

A certified technician from Energy Northwest annually tests the weights used for the daily calibration of the drum scale. The weights are tested by direct comparison with standard weights using the drum scale. Appendix 1 is a photocopy of the calibration history of the weights. The 200-lb weights were purchased and first calibrated in 2003. The 100-lb weights were added in 2004.

A Fluor technician attended a training class on August 31 - September 2, 2004 by Mettler Toledo $^{(i)}$ to ensure that the calibration of the drum scale, using the certified weights, was being done in accordance with the latest manufacturer's guidance. The target accuracy for the calibration effort was plus or minus $0.1 \mathrm{lb}$. During previous discussions with the Mettler Toledo ${ }^{(B)}$ representative, our technician inquired as to the ability of the scale to maintain such a tight accuracy band. Mettler Toledo ${ }^{(i)}$ said that although that was possible, a plus or minus $0.2 \mathrm{lb}$ band was what they recommended for these scales.

\section{Conclusion}

The balances used to (1) weigh 3013 containers prior to placement in 9975 shipping packages and (2) weigh the loaded and closed 9975 shipping packages consistently stay within tight tolerances. Neither balance indicates a pattern of "drift" that might make it more difficult to maintain within tolerances in the future. More importantly, the PFP Instrument Technicians have demonstrated their ability to return the balances within tolerances whenever either indicates weights outside allowable tolerances, even if the deviation exists at only one check weight. Daily checks (when in use) minimize the number of containers that might need reweighed if a balance slips out of tolerance. 


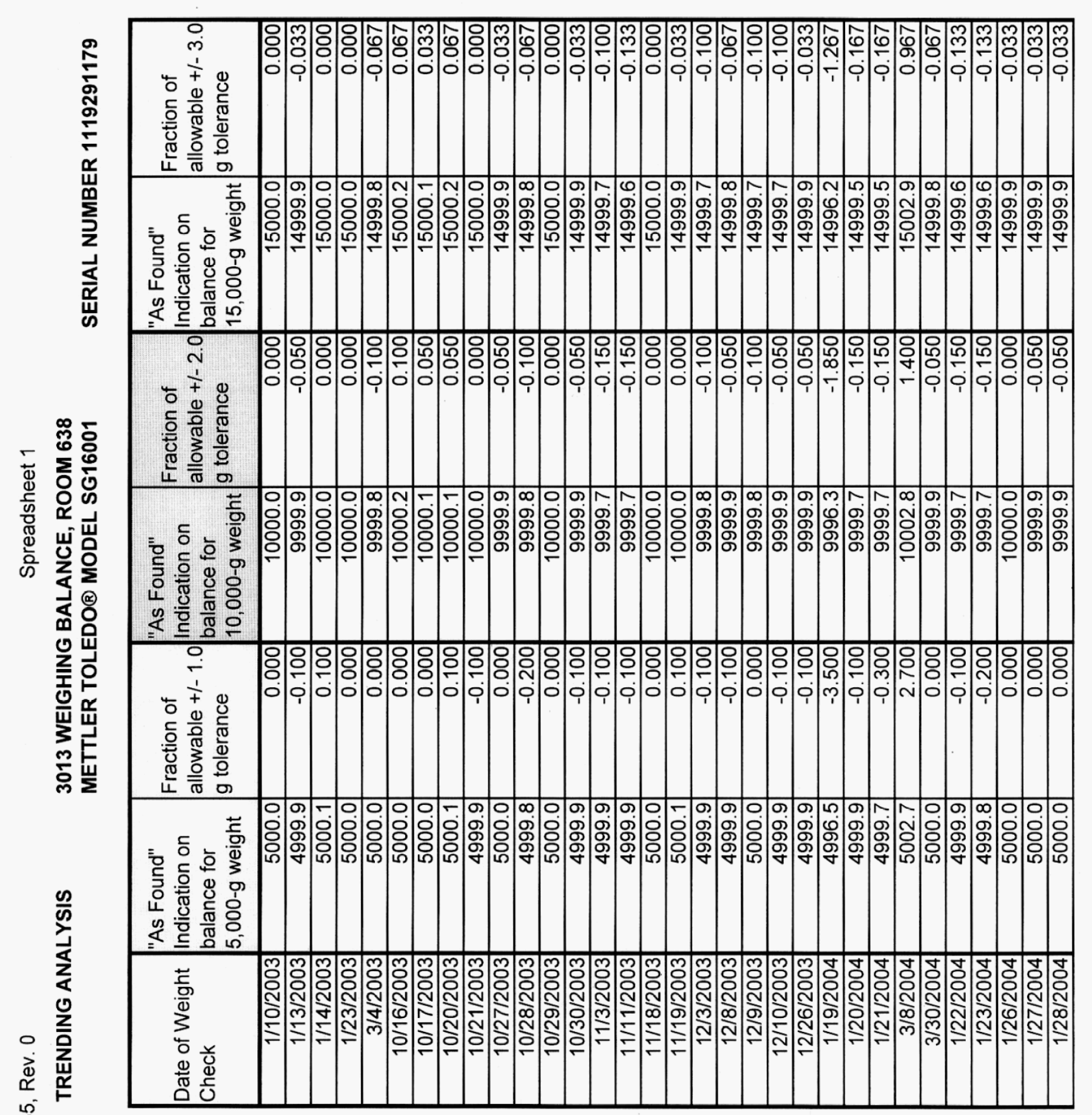




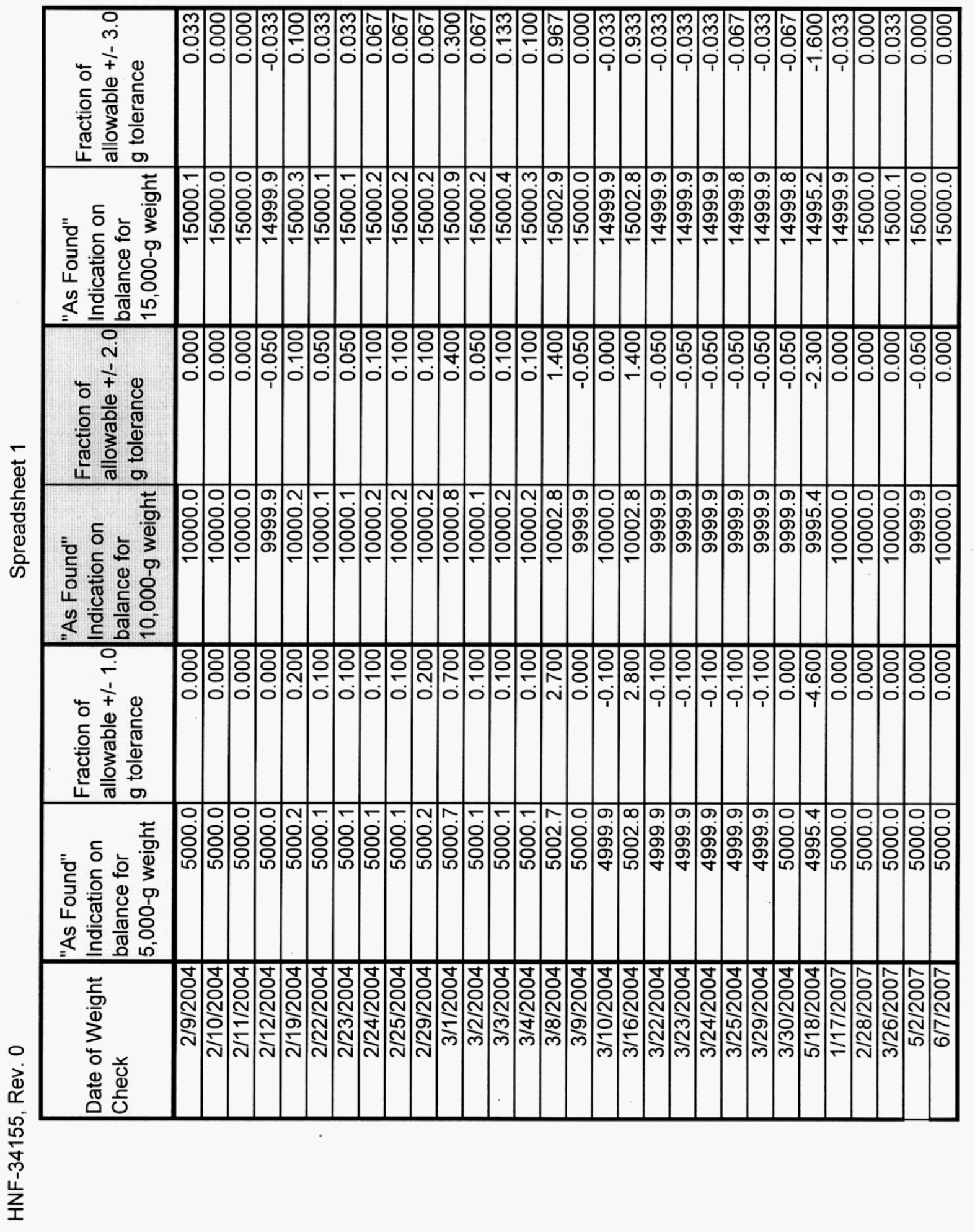




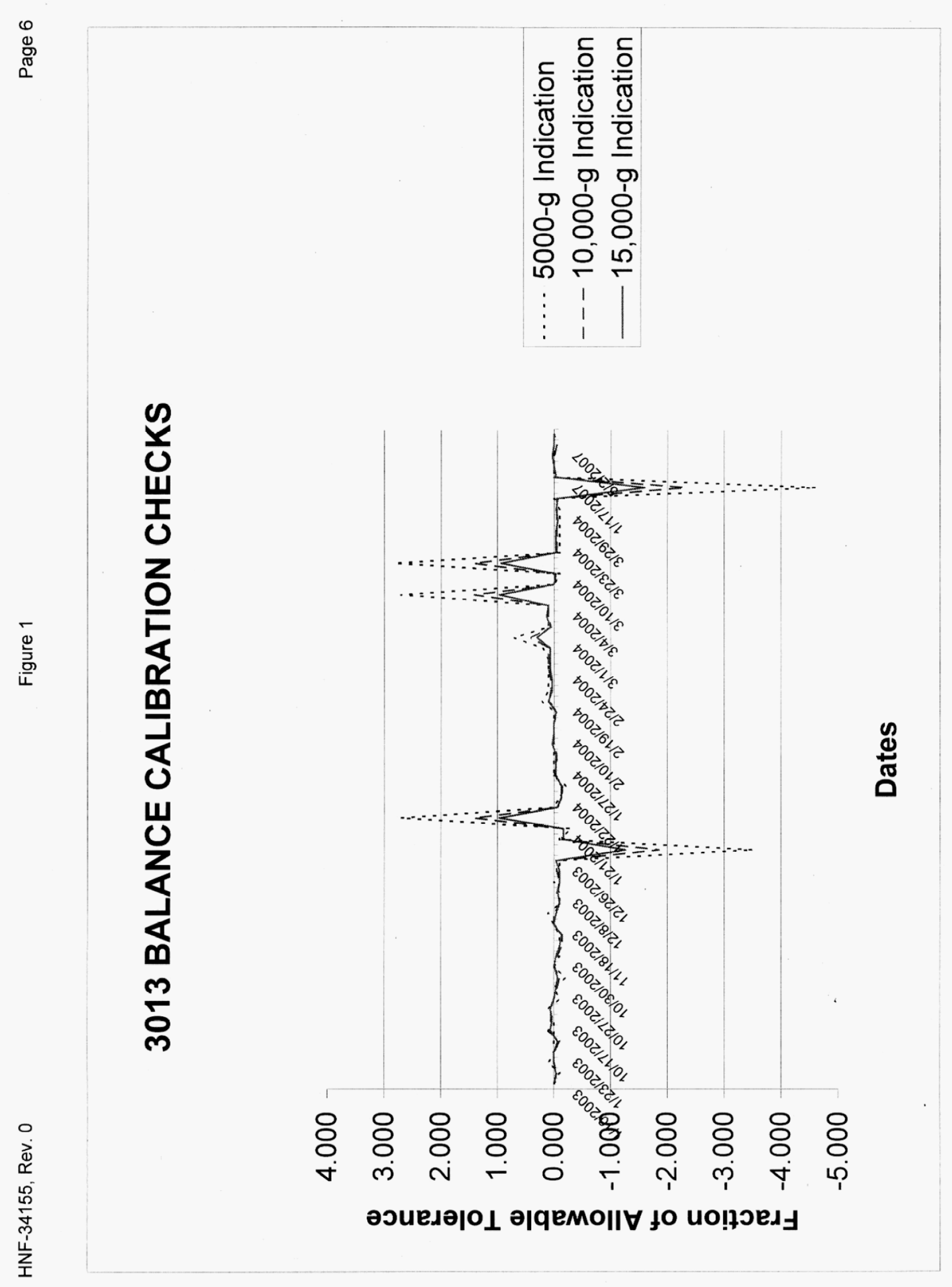

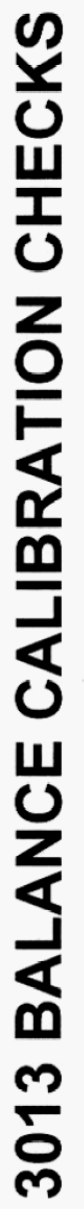

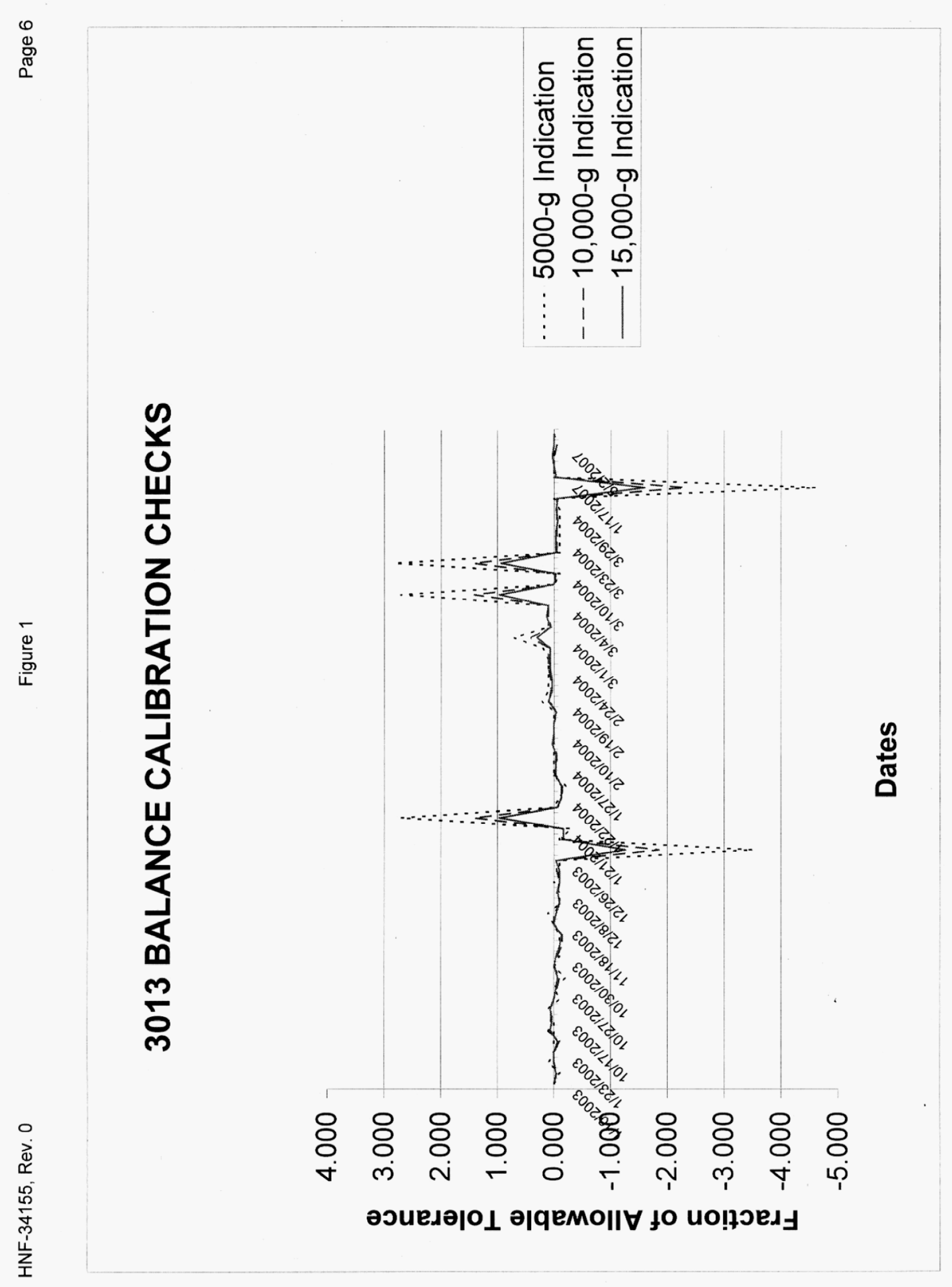

号

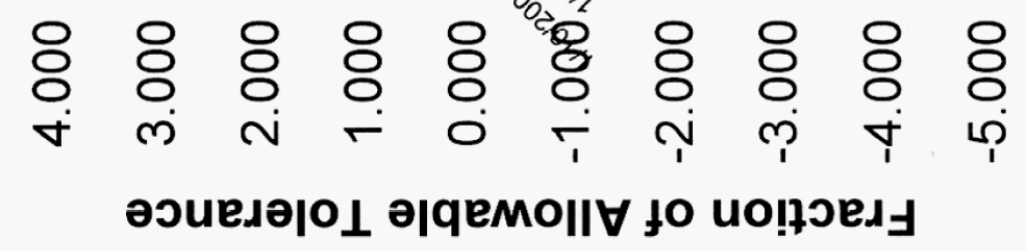

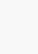


ヘ
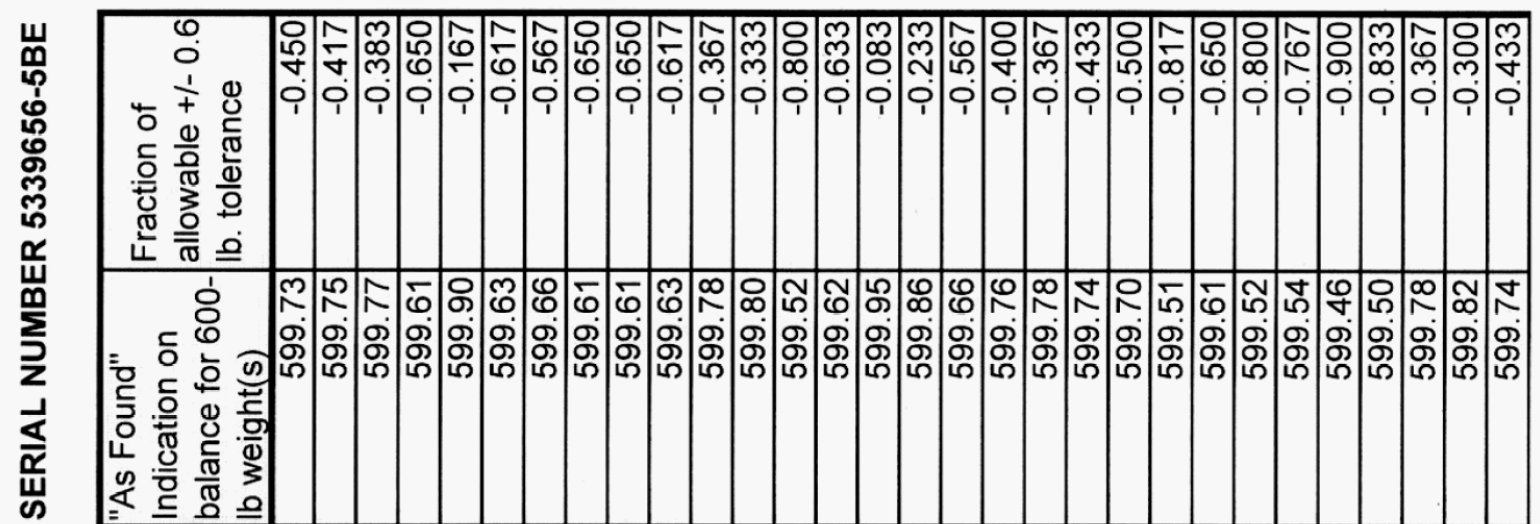

๘ :

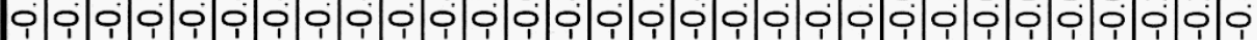

든 $\frac{0}{0}$

은 은 $\frac{0}{0} \frac{10}{0}$

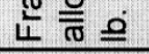

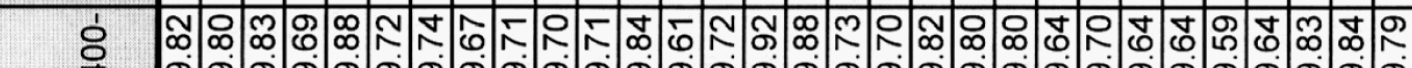
○ ᄃ

든 는

난 융 응

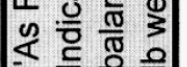

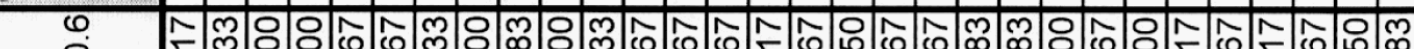

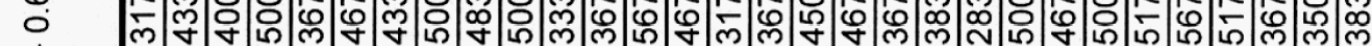

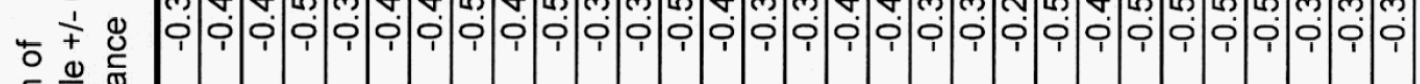

든 응

空

立 䯧

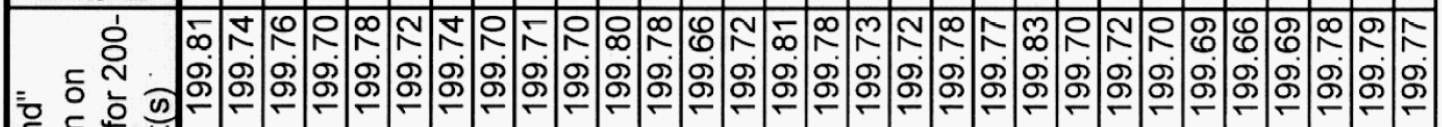
드은 눈 을 仓 里施

O

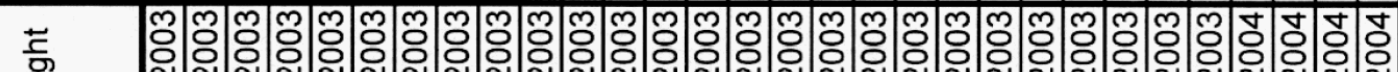
然 范 
$\infty$
வ
வ

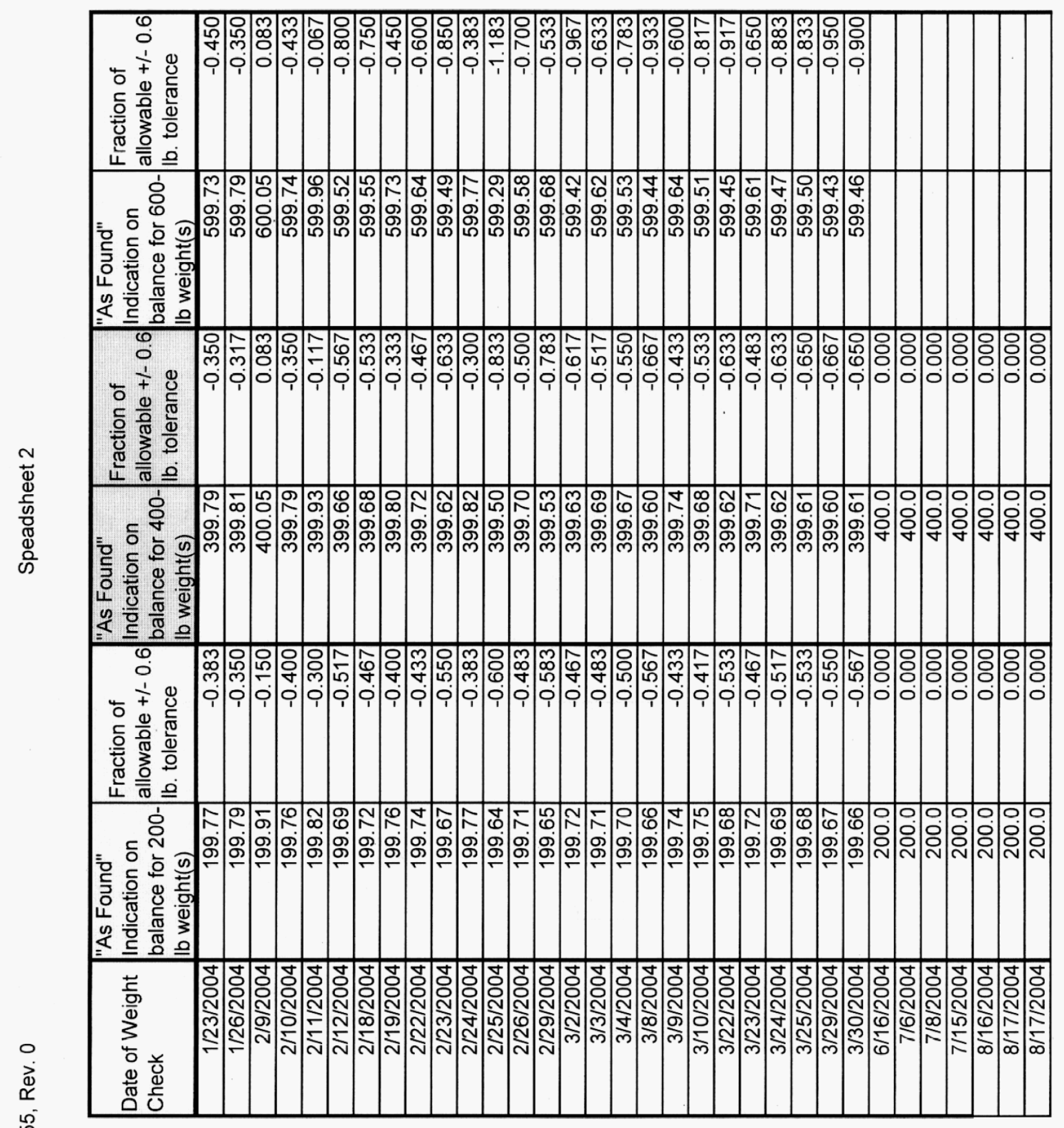




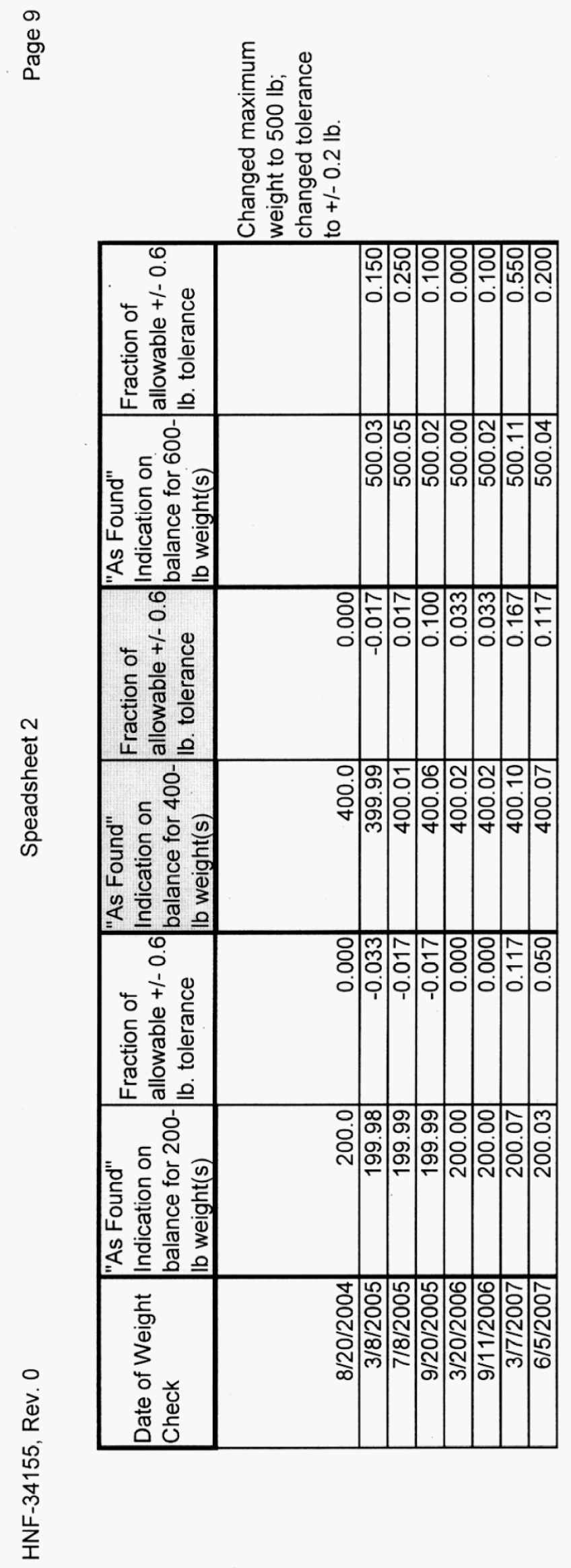




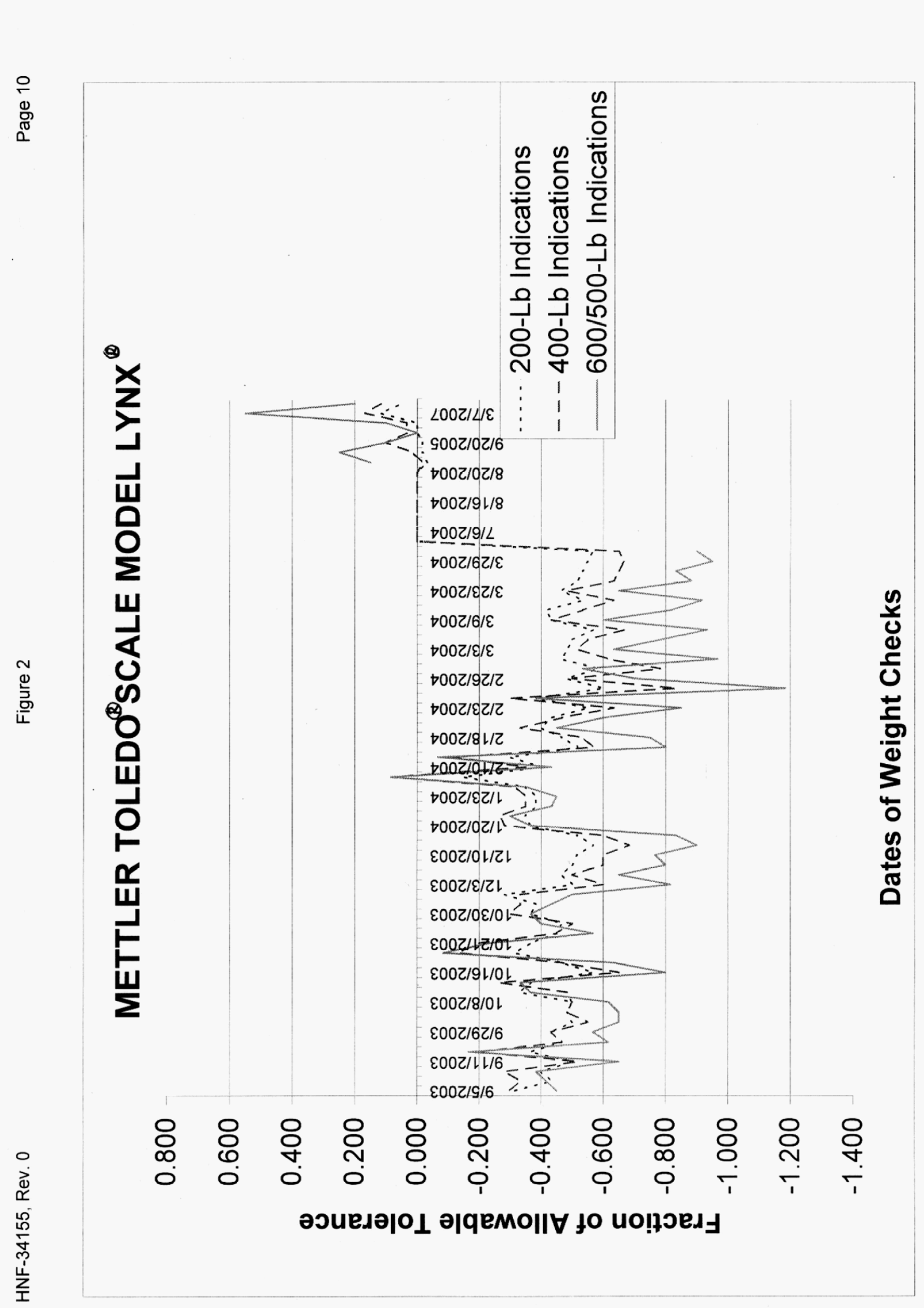


Appendix 1

Calibration History of Weights 

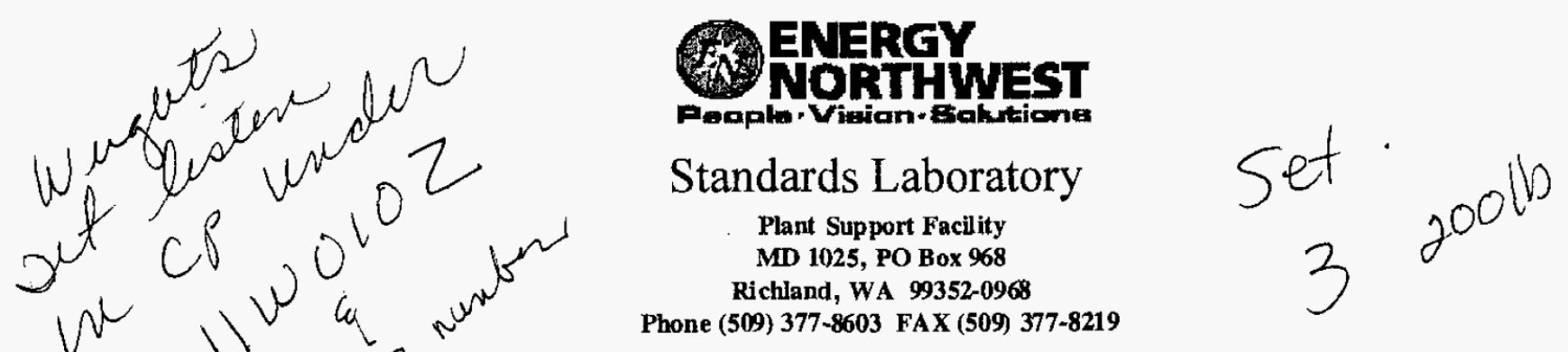

$v^{p^{3}} \quad$ Certificate of Calibration

Manufacturer: RICE LAKE

Description: WEIGHT AVOIRDUPOIS

Report Number: 1061568145

Release Number:

Customer / MSIN: GARRISON SM / T5-02
Model: N/A

Asset Number: 840-86-01-006

Serial Number: 11W010Z/11W011z/ilwo/2 Z

Ref. Number: 03-00559

Building: 234-5

\section{CALIBRATION INFORMATION}

\section{Test Conditions:}

Receive Date: 17-Mar- 103

Calibration Date: 22-Aug-03

Calibration Due: 22-Aug-04

Technician: W. E. CALLAWAY
Procedure / Rev: 30-2 Rev. 4

Temperature: $25.0 \mathrm{C}$

Humidity: $0 \%$

Test Results:

$\begin{array}{ll}\text { Pass: } & \mathrm{Y} \\ \text { Incomplete: } & \mathrm{N} \\ \text { Limited: } & \mathrm{N} \\ \text { As Found: } & \text { PASS } \\ \text { As Left: } & \text { PASS } \\ & \\ \text { Remarks: } & \text { CALIBRATED IN-PLACE (3) } 200 \text { LB. WEIGHTS. }\end{array}$

\section{STANDARDS USED FOR CALIBRATION}

Asset Number

002-79-06-003

003-86-01-003

Manuf
SOAR
HOW

Model

TX-201C

HOWE
Description

THERMOMETER

WEIGHT AVOIR
Calibration Date Due Date

$1 / 20 / 2003$

$1 / 20 / 2004$

$10 / 24 / 2001$

Notes/General Conditions:

The standards and calibration program of the Energy Northwest Standards Laboratory complies with the requirements of 10 CFR50 Appendix B and ANSI/NCSL Z-540-1.

Unless other wise noted:

The

standards used in this calibration, described in the referenced calibration procedure with associated uncertainties or tolerances, are traceable to the National Institute of Standards and Technology (NIST). The total uncertainties or tolerances of the standards used are no greater than $25 \%$ of the tolerance of the unit tested. There are no special limitations of use imposed on this item. This Report may not be reproduced, except in full, without the permission of the Energy Northwest Standards Laboratory.
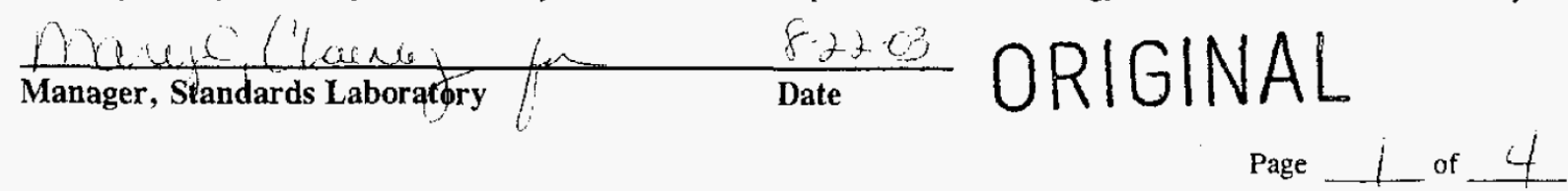
WNE-34155, Rev, 0

\begin{tabular}{|l|l|l|l|l|l|}
\hline & & \\
\end{tabular}

MASS CAILBRATED BY DIRECT COMPARISON WEIGHING.

CALIBRATION DATA

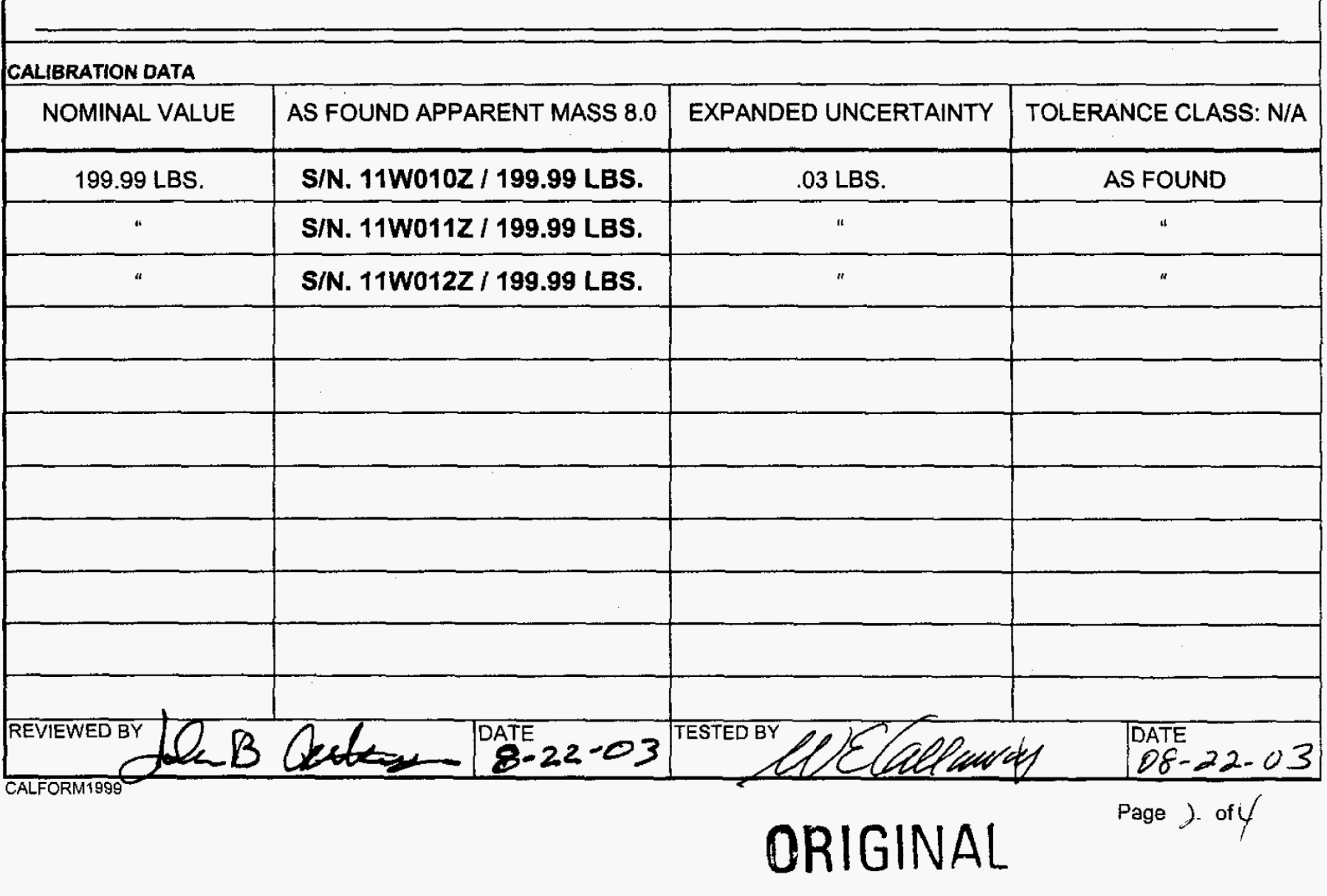

\section{ABORATORY}

列

234-5 TOOCRIB

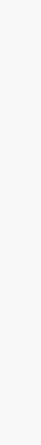




$$
\begin{aligned}
& \text { WNF-34155, Revo } \\
& 840-86-01-006
\end{aligned}
$$

199.86

199.82

199.82

199.82

199.82

199.81

199.79

199.83

199.83

199.82

0.017512
$.03 @ 95 \%$ confidence interval 
HNF- 34155, kev 0

Standards Laboratory

Calibration Certificate
Kootenal Blds 34

MD 1025, PO Box 968

Ruchland, WA 99352-0968

Thone (509) 377- 8444 FAX (509) 377-8219

ASSET INFORMATION

Manufacturer:

Description:

Report Number:

Release Number:

Customer / MD:
RICE LAKE

WEIGHT AVOIRDUPOIS - 5 EACH 1093011285

Abramsin D wipp/T4-20 ADRAHSONDO
Model:

Asset Number:

Serial Number:

Ref/PO Number:

Building:
N/A

840-86-01-006

See Page 2.

04-01715

234-5

CALIBRATION INFORMATION

Test Conditions:

\begin{tabular}{|c|c|c|c|c|c|c|}
\hline Receive Date & Calibration Date & Due Date & Temperature & Humidity & Procedure / Revision & Calibration Specificatipn \\
\hline 18-Aug-04 & 20 -Aug-04 & 20 -Aug-05 & $77 \mathrm{~F}$ & $0 \%$ & $30-2 / 4$ & Customer \\
\hline
\end{tabular}

Test Results:

\begin{tabular}{|c|c|c|c|c|c|}
\hline Pass & Limited & AS FOUND & AS LEFT & Technician & Remarks \\
\hline $\mathrm{Y}$ & $\mathrm{N}$ & In-Tolerance & In-Tolerance & WE Callaway & See Attached Report w/ Remarks \\
\hline
\end{tabular}

Standards Used for Calibration:

\begin{tabular}{|c|c|c|c|c|c|}
\hline Asset Number & Manufacturer & Model & Deseription & Callbration Date & Due Date \\
\hline $002-79-06-003$ & SOAR & TX-201C & THERMOMETER & $2 / 5 / 2004$ & $2 / 5 / 2005$ \\
\hline $003-86-01-003$ & HOWE & HOWE & WEIGHT AVOIR & $11 / 4 / 2003$ & $11 / 4 / 2005$ \\
\hline
\end{tabular}

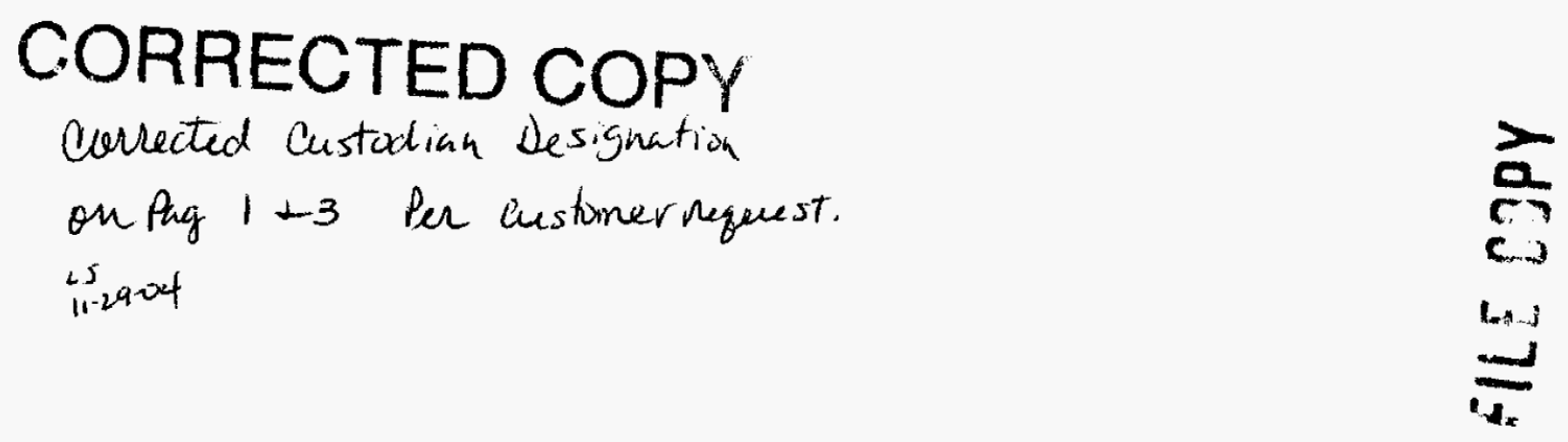

Notes/General Conditions:

The standards and calibration program of the Energy Northwest Standards Laboratory complies with the requirements of 10 CFR50 Appendix B and ANSU/NCSL Z-540-1-1994.

The standards used in this calibration as described above, and their associated uncertainties or tolerances, are traceable to the National Institute of Standards and Technology (NIST) or nationally accepted intrinsic standards. The total uncertainties or tolerances of the standards used are no greater than $25 \%$ of the tolerance of the unit tested, unless otherwise noted. This Report may not be reproduced, except in full, without the permission of the Energy Northwest Standards Laboratory.

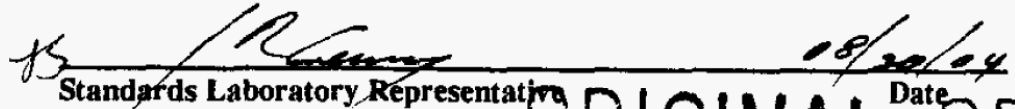




\section{MNF-34155, Revo Page A-6 04:2715 STANDARDS LABORATORY}

REPORT OF CALIBRATION

\section{People -Vision·Solutions}

\begin{tabular}{|c|c|c|c|}
\hline $\begin{array}{l}\text { MANUFACTURER: } \\
\text { RICE LAKE }\end{array}$ & $\begin{array}{l}\text { MODEL: } \\
\\
200 / 100 \text { LBS. }\end{array}$ & WE CALLAY & \\
\hline $\begin{array}{l}S / N: \\
11 W 010 z / 11 \text { W11ZJ11W }\end{array}$ & \begin{tabular}{|r|r|}
$35 z / 11 W 036 z$ & CAL CODE \\
8
\end{tabular} & $\begin{array}{r}\text { AMBIENT TEMP: } \\
25^{\circ} \mathrm{C}\end{array}$ & $\begin{array}{r}\text { HUMIDITY: } \\
\text { N/A }\end{array}$ \\
\hline $\begin{array}{l}\text { CAL DATE: } \\
\\
\quad 08-20-04\end{array}$ & AS FOUND: & PROCEDURE: & REV: \\
\hline
\end{tabular}

\section{REMARKS:}

MASS CALIBRATED USING DIFFERENTAL WEIGHING

\section{CALIBRATION DATA}

\begin{tabular}{|c|c|c|c|}
\hline NOMINAL VALUE & AS FOUND APPARENT MASS 8.0 & EXPANDED UNCERTAINTY & TOLERANCE CLASS: N/A \\
\hline 200.000 LBS. & S/N. 11W010Z / 200.01 LBS. & .03 LBS. & AS FOUND \\
\hline “ & S/N. 11W011Z / 200.04 LBS. & “ & . \\
\hline “ & S/N. 11W012Z/200.01 LBS. & “ & “ \\
\hline 100.000 LBS. & S/N. 11W035Z / 100.01 LBS. & $“$ & $"$ \\
\hline “ & S/N. 11W036Z/ 100.01 LBS. & “ & “ \\
\hline & & & . \\
\hline & & & \\
\hline & & & \\
\hline & & & \\
\hline & & & \\
\hline & & & \\
\hline & & & \\
\hline & & & \\
\hline
\end{tabular}




$$
\text { HNF-34155, Rev. } 0
$$

\section{Quinn, Karen L}

From: DeRosa, David C

Sent: Tuesday, September 20, 2005 10:31 AM

To: $\quad$ McCollum, C R (Rick); Quinn, Karen L; Schumacher, Ronald F; Huggins, Stewart L

Cc: Abramson, Debi; 'jremery@energy-northwest.com'; Oliver, F Ben; Sutter, Caroline S; Peale, Debra D; Sutherland, Aprilly S; Franklin, Laurie D; Woodruff-Shaw, Janice L

Subject: RE: weight set 840-86-01-006

I approve -

David DeRosa

From: McCollum, C R (Rick)

Sent: Tuesday, September 20, 2005 10:26 AM

To: Quinn, Karen L; Schumacher, Ronald F; DeRosa, David C; Huggins, Stewart L

Cc: Abramson, Debi; 'jremery@energy-northwest.com'; Oliver, F Ben; Sutter, Caroline S; Peale, Debra D;

Sutherland, Aprilly S; Franklin, Laurie D; Woodruff-Shaw, Janice L

Subject: RE: weight set 840-86-01-006

Karen, Changes in interval on WIPP related equipment also require approval of Dave Derosa, the WIPP Site Project Manager, and Stu Huggins, the WIPP Site Quality Assurance Officer. I am forwarding this email to them to receive that approval. When the weights are recalibrated, the calibration interval should be adjusted to five years, based on the use of the weights as check weights with an expanded uncertainty of 0.03 ibs. to check a Fairbanks scale with an accuracy of $+/-10 \mathrm{lbs}$., and their cast iron construction with tight controls on care and handling. Please work with Caroline Sutter to transmit the calibration certificates to WIPP records and I'Il add the weights to the WIPP Calibrated Equipment List. Call me if you have other questions.

Rick McCollum

$376-8989$

845-2101

From: Quinn, Karen L

Sent: Tuesday, September 20, 2005 8:32 AM

To: Schumacher, Ronald $F$

Cc: Abramson, Debi; 'jremery@energy-northwest.com'; Oliver, F Ben; Sutter, Caroline S; Peale, Debra D;

Sutherland, Aprilly S; Franklin, Laurie D; Quinn, Karen L; Woodruff-Shaw, Janice L; McCollum, C R (Rick)

Subject: weight set 840-86-01-006

The weight set 840-86-01-006 expired on Aug.20,2005 we are needing an extension and justification of its calibration certificate till Oct 20,2005 this is $\$ 50.00$. We then will have Energy Northwest come out and do a recalibration before this time expires.

Ron please forward this to Jim Emery at Energy Northwest with your concurrence that this is satisfactory, I'm faxing the order number down to energy northwest.

Thank you

Karen Quinn

PFP Tool Crib

$373-4648$ 
Page 22 of 33 of DA 05252680

Routine Calibration Services - Order \# 03-00559 HNF - 34155, Rev. 0

Page 1 of 1 Page A-

Routine Calibration Services

Order \# 03-00559 Order Date 03/16/2003

Equipment information:

SCI: $111-11-11-111 \quad 840-86211004$ Manufacturer: NEW EQUIPMENT Model: NEW EQUIPMENT Serial Number: NEW EQUIPMENT Description: NEW EQUIPMENT. Calibration Range \& Tolerance and Special Calibration Instructions: ENTER MFG, MDL NO., S/N, DESC, AND CAL RANGE AND TOLERANCE Rice lakes, Weight Set, 200 lbs EA. Calibrate to manufacturer specification. IN House total 600 lbs. 3 weights. Will call for date.

Quality/lnspection Information:

Quality Level: 1

Safety Classification: SC

QAE: Goth Don

QAE Phone: 509-373-5029

Approved QAIP on File wi AVS? Yes CACN: 116486

COA: AF 20

Designated Equipment: NONE Cost Information:

Expedite: No

Requested Return Date: nsa

Unit Price: 400.00

Task Order Price: 400.00

Equipment Custodian:

P-Card Log Number: ho065674-6289 Custodian: Epps Carolyn

Phone: 509-373-4648 MIN: T5-02

Deliver To:

234-5 toolcrib

Return $(3-1723)$-originally logged in $8-21-0.3$

set.
$100010 \mathrm{Z}$

$19 \omega 011 z$

ip old z. 


$$
\text { WNF-34155, Rev.o }
$$

Standards Laboratory Calibration Certificate

Kootenil Bld 34

MD 10ns, PO Bex 9

Richlind, WA sosse-ces

Fhens (Fes) 3M- 8444 FAX (Fes) 37-2219

ASSET INFORMATION

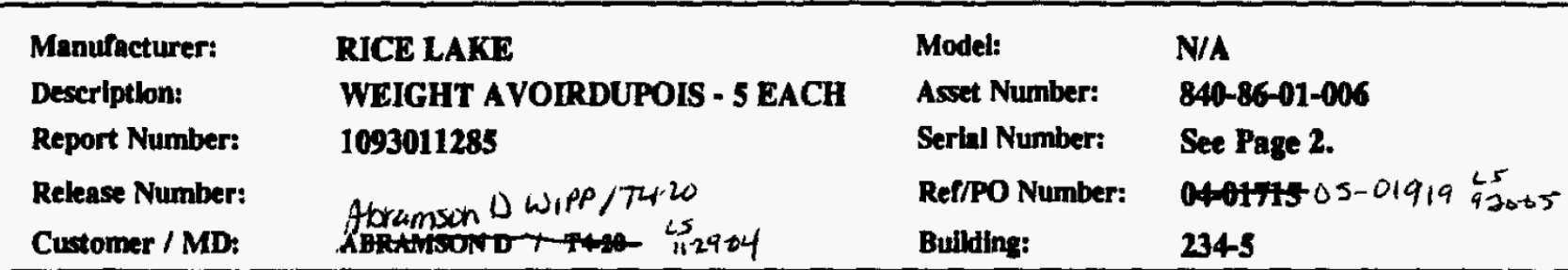

CALIBRATION INFORMATION

Test Conditions:

\begin{tabular}{|c|c|c|c|c|c|c|}
\hline Receive Dato & Calibration Date & Due Date & Temperature & Humidity & Procedure / Revision & Calibration Specification \\
\hline 18-Aug-04 & 20-Aug-04 & $20-A u g-05$ & $77 \mathrm{~F}$ & $0 \%$ & $30-2 / 4$ & Customer \\
\hline \multicolumn{7}{|c|}{ Test Results: } \\
\hline Past & Limitad & \multicolumn{2}{|c|}{ AS FOUND } & AS LEFT & Technician & Remarks \\
\hline $\mathbf{Y}$ & $\mathbf{N}$ & \multicolumn{2}{|c|}{ In-Tolerance } & In-Tolerance & WE Callaway & See Attached Repart w/ Remarts \\
\hline
\end{tabular}

Standards Used for Calibration:

\begin{tabular}{|c|c|c|c|c|c|}
\hline Assut Number & Menufecturer & Moded & Deseription & Callbratton Date & Dus Date \\
\hline $002-79-06-003$ & SOAR & TX-201C & THERMOMETER & $2 / 5 / 2004$ & $2 / 5 / 2005$ \\
\hline $003-86-01-003$ & HOWE & HOWE & WEIGHT AVOIR & $11 / 4 / 2003$ & $11 / 4 / 2005$ \\
\hline
\end{tabular}

$$
\begin{aligned}
& \text { CORRECTED COPY } \\
& \text { corrected Custodian designation } \\
& \text { on Ping } 1+3 \text { Per customernequest. } \\
& 11.5 \text { a. at } \\
& \text { THE REVIEW OF THE CALIBRATIN IHSTORY SHOWS THESE WELAFTS HRE STABCE. } \\
& \text { A CALIBRATION EXTENSION Of ThO (2) MONTHS IS GRATED IN OROER } \\
& \text { FOR USER TO MEET CURNGNT WORK IN PRASRESS. } \\
& \begin{array}{l}
0 \\
0.7 \\
0.1 \\
0.1
\end{array}
\end{aligned}
$$

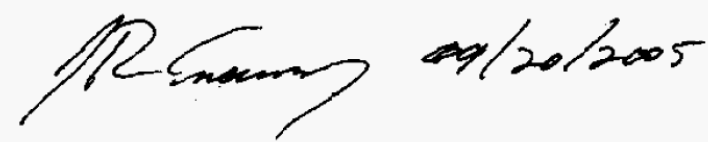

Notes/General Conditions:

The standards and calibration program of the Energy Nortliwest Standards Laboratory complies with the requirements of 10 CFR 50 Appendix B and ANSINCSL Z-540-1-1994.

The standards used in this calibration as described above, and their associated uncertainties or tolerances, are traceable to the National Institute of Standards and Technology (NIST) or nationally accepted intrinsic standards. The total uncertainties or tolerances of the standards used are no greater than $25 \%$ of the tolerance of the unit tested, unless otherwise noted. This Report may not be reproduced, except in full, without the permission of the Energy Northwest Standards Laboratory.

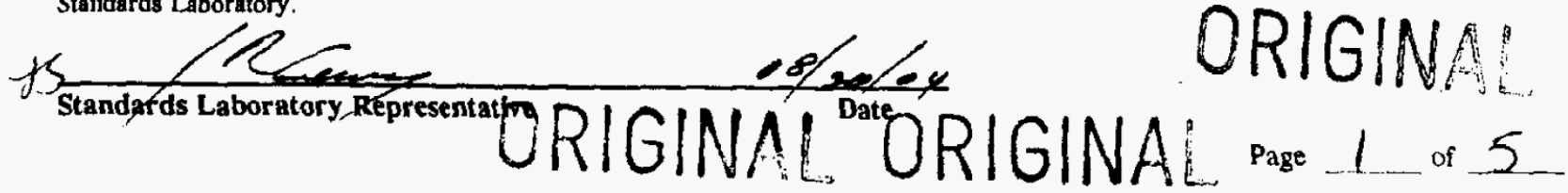




\section{STANDARDS LABORATORY}

REPORT OF CALIBRATION

\section{People.Vision.Solutions}

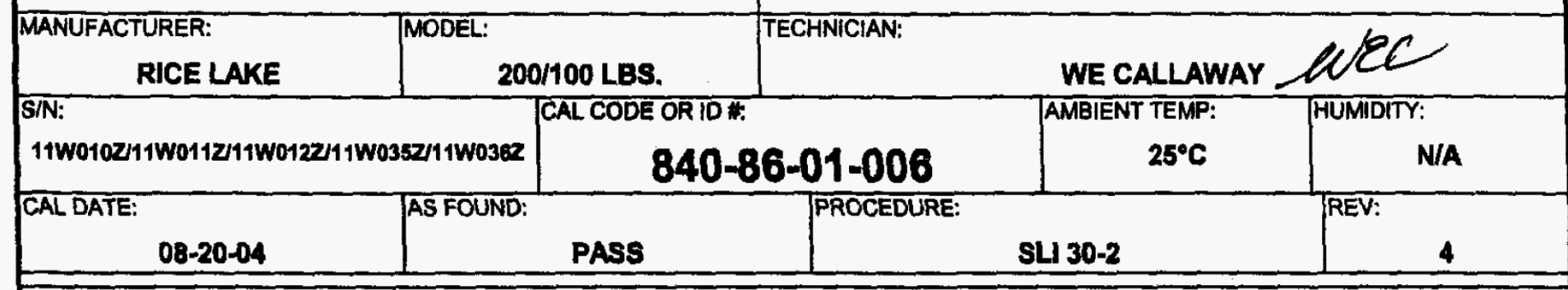

REMARKS:

CALIBRATION DATA

\begin{tabular}{|c|c|c|c|}
\hline NOMINAL VALUE & AS FOUND APPARENT MASS 8.0 & EXPANDED UNCERTAINTY & TOLERANCE CLASS: N/A \\
\hline 200.000 LBS. & S/N. 11W010Z/ 200.01 LBS. & .03 LBS. & AS FOUND \\
\hline “ & S/N. 11W011Z/200.04 LBS. & “ & “ \\
\hline “ & S/N. $11 W 012 Z$ / 200.01 LBS. & $"$ & $"$ \\
\hline 100.000 LES. & SIN. 11W035Z / 100.01 LBS. & “ & $“$ \\
\hline " & SN. 11W038Z/ 100.01 LBS. & “ & $“$ \\
\hline & & & \\
\hline & & & \\
\hline & & & \\
\hline & & & \\
\hline & & & \\
\hline & & & \\
\hline & & & \\
\hline
\end{tabular}


Page 25 of 33 of $\mathrm{DA} 05252680$

$$
\text { NNF-34155, ReNo }
$$

Page A-11-...

Routine Calibration Services

Order \# 04-01715

Order Date 08/19/2004

Equipment information:

SCN: 840-86-01-006

Manufacturer: RICE LAKE

Model: N/A

Serial Number: 11W010Z/11W0112

Description: WEIGHT AVOIRDUPOIS

Calibration Range Tolerance and Special Calibration Instructions:

CALIBRATED IN-PLACE (3) 200 LB. WEIGHTS. Add (2) 100 LB. WEIGHTS TO

SET. CALIBRATE 200 10. WEIGHTS TO LAST REPORT. CALIBRATE 100 LB.

WEIGHTS TO 100 LBS:

Quallty/lnspection Information:

Quality Level: 1

Safety Clacofilcation: SC

QAE: Don Froth

QAE Phone: 509-373-5029

Approved QAIP on File wi AVS? Yes

CACN: 119262

DOA: FAB

Designated Equipment: HONE WI PP ${ }_{112904}$

Cost Information:

Expedite: Yes 2.0 for next on bench (24 hour)

Requested Rectum Date: 8/19/04

Unit Price: 371

Task Order Price: 742

Add $100=0$ for Trip.

Equipment Custodian:

PiCard Log Number: H0065674-8146

Custodlen:earter-Mark-Abramson D Wipp/T4-20

Phone: 509-373-4648

MIN: T5-02

11-2924

Deliver To:

In House

Return 81804

sin in fo from Bill

In -Place

11 w0102 1160352

$11 w 01 z \cdot 11 w 036 z$

$11 W 012 z$

Set of 5 (3) $200 \mathrm{lbs} \mathrm{sn}^{\prime} \mathrm{s}-$

(d) $100 \mathrm{lbs}$ sh's -

ORIGINAL

ORIGINAL

http://apweb02.rl.gov/rapidweb/phmc/procweb/calibration/calibrationPrint.cfm

$8 / 19 / 2004$

Page 3 of 5 


\section{Routine Calibration Services}

Order \# 05-01592

Order Date 07/25/2005

\section{Equipment Information:}

SCN: 840-86-01-006

Manufacturer: RICE LAKE

Model: N/A

Serial Number: See Page 2.

Description: WEIGHT AVOIRDUPOIS - 5 EACH

Calibration Range \& Tolerance and Special Calibration Instructions:

Quality/Inspection Information:

Quality Level: 1

Safety Classification: SC

QAE: Groth, Don

QAE Phone: 509-373-5029

Approved QAIP on File w/ AVS? Yes

CACN: 119282

COA: KA10

Designated Equipment: WIPP $7 / 25 / 05$

Cost Information:

Expedite: No

Requested Return Date: n/a

Unit Price: 3

Task Order Price: 379

* $50^{\circ}$ Calibration extension

Equipment Custodian:

P-Card Log Number: h0065674-9880

Custodian: Abramson,Debi

Phone: 509-373-5508

MSIN: T5-02

Deliver To:

PFP Tool Crib

373-4648

Return Rm 638 Building $2736-Z B$ 
ANERG NORTHWEST Emapla viabion+Eehutione

\section{HNF-34155, ReV.O. \\ Standards Laboratory $\sqrt{ }{ }_{\text {Kootenal Bddg } 34}$ \\ MD 1025, PO Box 968 \\ Richland, WA 99352-0968 \\ Phone (509) 377- 8444 FAX (509) 377-8219}

ASSET INFORMATION

Manufacturer:

Description:

Report Number:

Release Number:

Customer / MD:
RICE LAKE

WEIGHT AVOIRDUPOIS - 5 EACH

1129648369
Model:

Asset Number:

Serial Number:

Ref/PO Number:

Building:
N/A

840-86-01-006

N/A

05-0159205-02145 $\underset{10}{5}$

234-5

CALIBRATION INFORMATION

Test Conditions:

\begin{tabular}{|c|c|c|c|c|c|c|}
\hline Receive Date & Calibration Date & Due Date & Temperature & Humidity & Procedure / Revision & Calibration Specification \\
\hline 25-Jul-05 & $18-$-Oct-05 & 18 -Oct-06 & $24 \mathrm{C}$ & N/A & $30-2 / 4$ & Customer \\
\hline
\end{tabular}

Test Results:

\begin{tabular}{|c|c|c|c|c|c|}
\hline Pass & Limited & AS FOUND & AS LEFT & Technician & Remarks \\
\hline $\mathrm{Y}$ & $\mathrm{N}$ & In-Tolerance & In-Tolerance & WE Callaway & See Attached Report w/ Remarks \\
\hline
\end{tabular}

Standards Used for Calibration:

Asset Number

Manufacturer

Model

Description

Calibration Date

Due Date

002-79-06-003

003-86-01-003

\section{SOAR}

HOWE

TX-201C

THERMOMETER

$2 / 18 / 2005$

$2 / 18 / 2006$

HOWE

WEIGHT AVOIR

$11 / 4 / 2003$

$11 / 4 / 2005$

\section{Notes/General Conditions:}

The standards and calibration program of the Energy Northwest Standards Laboratory complies with the requirements of 10 CFR50 Appendix B, ASME NQA-1 (1989), and ANSI/NCSL Z-540-1-1994.

The standards used in this calibration as described above, and their associated uncertainties or tolerances, are traceable to the National Institute of Standards and Technology (NIST) or nationally accepted intrinsic standards. The total uncertainties or tolerances of the standards used are no greater than $25 \%$ of the tolerance of the unit tested, unless otherwise noted. This Report may not be reproduced, except in full, without the permission of the Energy Northwest Standards Laboratory.

\section{ORIGINAL}

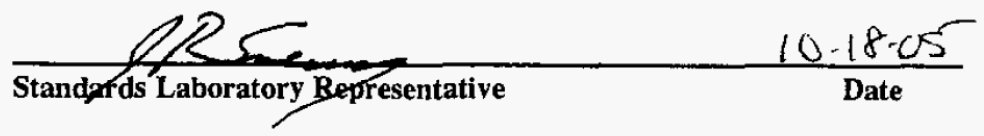

Page $\perp$ of 3 


\section{STANDARDS LABORATORY}

REPORT OF CALIBRATION

\section{People.Vision. Solutions}

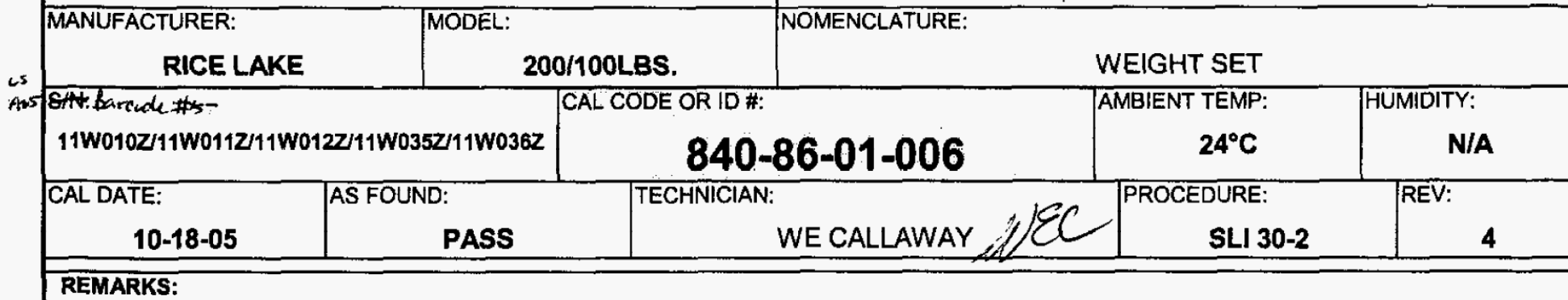

MASS CALIBRATED USING DIFFERENTAL WEIGHING

CALIBRATION DATA

\begin{tabular}{|c|c|c|c|}
\hline NOMINAL VALUE & AS FOUND APPARENT MASS 8.0 & EXPANDED UNCERTAINTY & TOLERANCE CLASS: N/A \\
\hline 200.000 LBS. & S/N. 11W010Z/200.01 LBS. & .03 LBS. & AS FOUND \\
\hline$“$ & S/N. 11W011Z/200.01 LBS. & " & " \\
\hline “ & S/N. 11W012Z/200.00 LBS. & " & " \\
\hline 100.000 LBS. & S/N. 11W035Z/100.00 LBS. & & \\
\hline$“$ & S/N. 11W036Z/100.00 LBS. & & \\
\hline & & & \\
\hline & & & \\
\hline & & & \\
\hline
\end{tabular}




$$
\text { WNF-34155, Rev.O }
$$

\title{
Routine Calibration Services
}

\author{
Order \# 05-02145
}

Order Date 10/17/2005

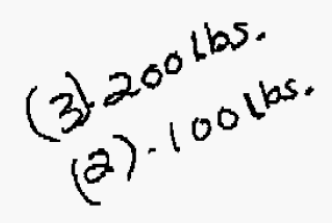

Equipment Information:

SCN: 840-86-01-006

Manufacturer: RICE LAKE

Model: N/A

Serial Number: N/A

Description: WEJGHT AVOIRDUPOIS - 5 EACH

Calibration Range \& Tolerance and Special Calibration Instructions:

FWONONTHEXTENSHONPER JREMERY 9-2005.

Quality/Inspection Information:

Quality Level: 1

Safety Classification: SC

QAE: Don Groth

QAE Phone: 509-373-5029

Approved QAIP on File wl AVS? Yes

CACN: 119282

COA: KA10

Designated Equipment: NONE

Cost information:

Expedite: No

Requested Return Date: n/a

Unit Price: 394

Task Order Price: 394 + 100 Travel

Equipment Custodian:

P-Card Log Number: h0065674-1169

Custodian: Debi Abramson.

Phone: 509-373-5508

MSIN: T4-20

Deliver To:

PFP Tool Crib

373-4648

Return

101805

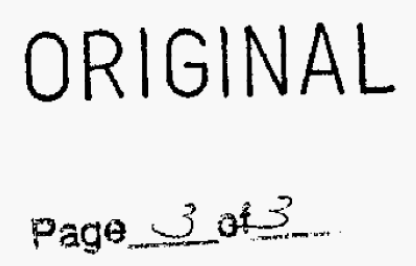

http://www2.rl.gov/rapidweb/phme/procweb/calibration/calibrationPrint.cfin 


\section{Standards Laboratory WNF-34/55, ker Rootenal Bldg 34 Page A- 16 Calibration Certificate

ASSET INFORMATION

\begin{tabular}{llll} 
Manufacturer: & RICE LAKE & Model: & N/A \\
Description: & WEIGHT AVOIRDUPOIS - & Asset Number: & $\mathbf{8 4 0 - 8 6 - 0 1 - 0 0 6}$ \\
Report Number: & $\mathbf{1 1 7 3 0 9 8 8 5 2}$ & Serial Number: & N/A \\
Release Number: & & Ref/PO Number: & $\mathbf{0 7 - 0 0 3 8 6}$ \\
Customer / MD: & RANSDELL RM WIPP / T5-50 & Building: & $\mathbf{2 3 4 - 5}$ \\
\hline
\end{tabular}

CALIBRATION INFORMATION

Test Conditions:

\begin{tabular}{|c|c|c|c|c|c|c|}
\hline Receive Date & Calibration Date & Due Date & Temperature & Humidity & Procedure / Revision & Calibration Specification \\
\hline $3 / 5 / 2007$ & $5-M a r-07$ & 5-Mar-08 & $20 \mathrm{C}$ & N/A & $30-2 / 4$ & Customer \\
\hline
\end{tabular}

Test Results:

\begin{tabular}{|c|c|c|c|c|c|}
\hline Pass & Limited & AS FOUND & AS LEFT & Technician & Remarks \\
\hline $\mathrm{Y}$ & $\mathrm{N}$ & In-Tolerance & In-Tolerance & GB Ohler sso & See Attached Report w/ Remarks \\
\hline
\end{tabular}

Standards Used for Calibration:

\begin{tabular}{|c|c|c|c|c|c|}
\hline Asset Number & Manufacturer & Model & Description & Cal. Date & Due Date \\
\hline 0064274 & WAHL & $700 \mathrm{MC}$ & THERMOMETER, HEAT PROBER & $12 / 11 / 2006$ & $12 / 11 / 2007$ \\
\hline $003-86-01-006$ & RICE LAKE & NA & WEIGHT AVOIRDUPOIS & $11 / 9 / 2005$ & $11 / 9 / 2007$ \\
\hline
\end{tabular}

Notes/General Conditions:

The standards and calibration program of the Energy Northwest Standards Laboratory complies with the requirements of 10 CFR50 Appendix B, ASME NQA-1 (1989), and ANSI/NCSL Z-540-1-1994.

The standards used in this calibration as described above, and their associated uncertainties or tolerances, are traceable to the National Institute of Standards and Technology (NIST) or nationally accepted intrinsic standards. The total uncertainties or tolerances of the standards used are no greater than $25 \%$ of the tolerance of the unit tested, unless otherwise noted. This Report may not be reproduced, except in full, without the permission of the Energy Northwest Standards Laboratory.

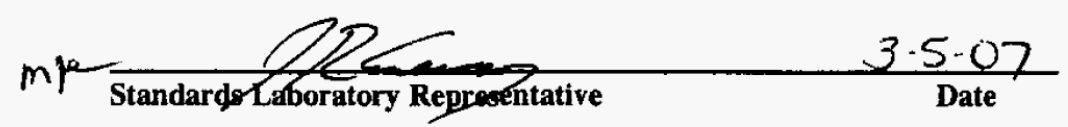

DRIGINAL

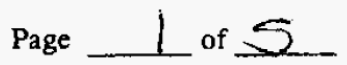


Standards Laboratory Page A-17

Calibration Report

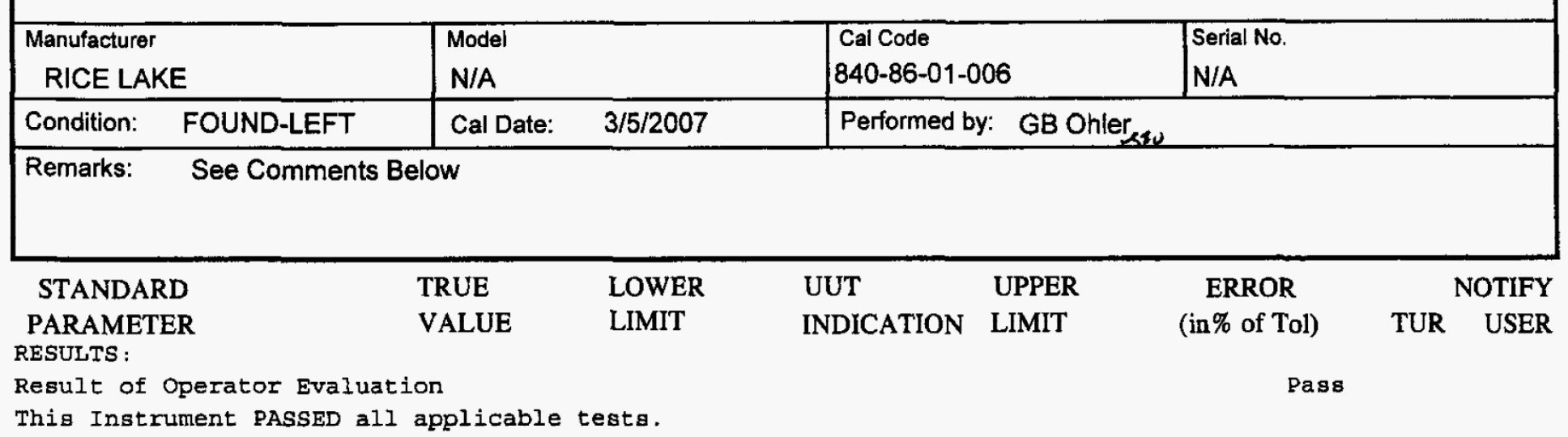

COMMENTS :

Reported Actual Mass Value

Mass Calibrated By Differential Weighing 


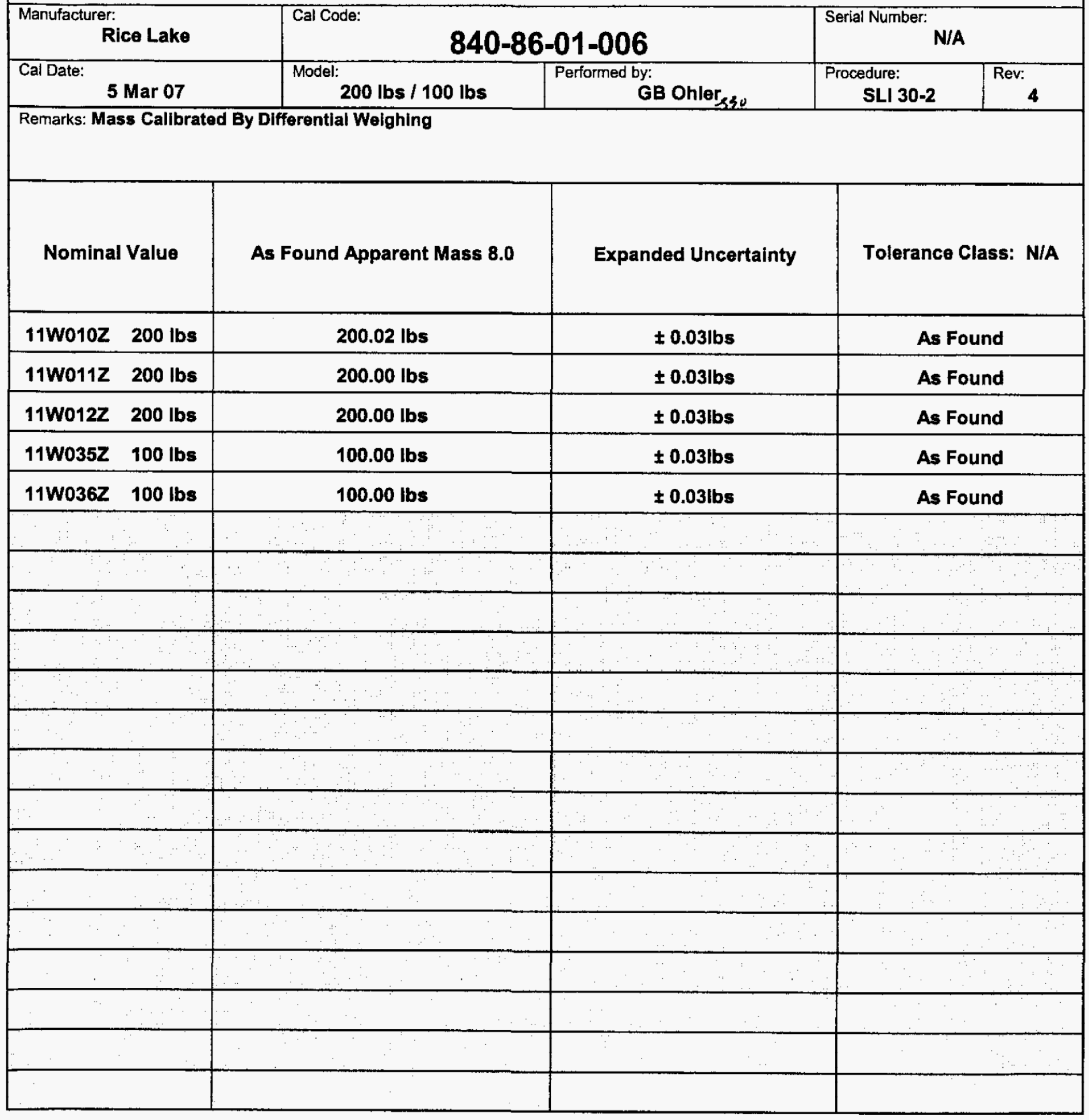 \\ Calibration Report People · Vision - Solutions \\ ENERGY NORTHWEST

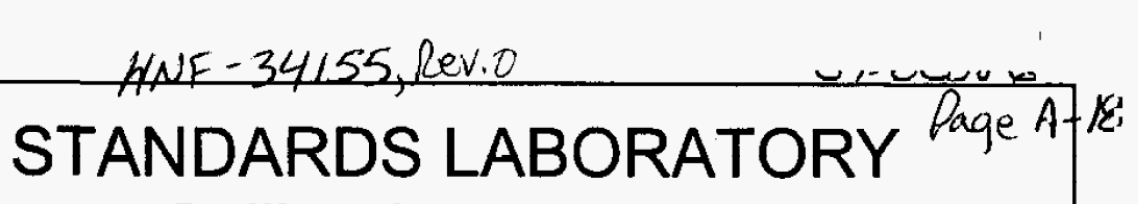 \\ .

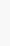

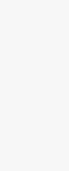
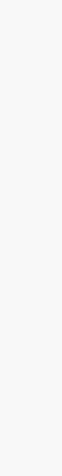

柆

(1)

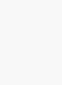




$$
\text { NNF-34155, Rev.0 }
$$

\section{Routine Calibration Services}

Order \# 07-00386

Order Date 02/28/2007

\section{Equipment Information:}

SCN: 840-86-01-006

Manufacturer: RICE LAKE

Model: N/A

Serial Number: N/A

Description: WEIGHT AVOIRDUPOIS - $5 \mathrm{EACH}$

Calibration Range \& Tolerance and Special Calibration Instructions:

3-200lbs and 2-100lbs. Certify to assigned specifications IN-HOUSE Calibration $\$ 100.00$

\section{Quality/lnspection Information:}

Quality Level: 1

Safety Classification: SC

QAE: Don Groth

QAE Phone: 509-373-5209

Approved QAIP on File w/ AVS? Yes

CACN: 119282

COA: KA10

Designated Equipment: WIPP

\section{Cost Information:}

Expedite: No

Requested Retum Date: n/a

Unit Price: $524 \quad 424$

Task Order Price: $524 \times 1.6+107.00=985.40$

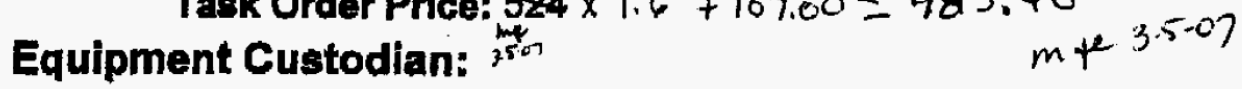

P-Card Log Number: h0065674-2767

Custodlan: Rick Ransdell

Phone: 509-373-5036

MSIN: T5-50

Deliver To:

234-5Z 200W Tool Crib 373-4648

Return

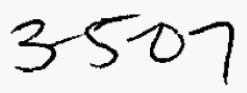

